\title{
Role of accessory components in the activation of vitamin K-dependent coagulation factors
}

Citation for published version (APA):

van Rijn, J. L. M. L., Zwaal, R. F. A., Hemker, H. C., \& Rosing, J. (1986). Role of accessory components in the activation of vitamin K-dependent coagulation factors. Haemostasis, 16(3-4), 216-226. https://doi.org/10.1159/000215294

Document status and date:

Published: 01/01/1986

DOI:

10.1159/000215294

Document Version:

Other version

\section{Please check the document version of this publication:}

- A submitted manuscript is the version of the article upon submission and before peer-review. There can be important differences between the submitted version and the official published version of record.

People interested in the research are advised to contact the author for the final version of the publication, or visit the DOI to the publisher's website.

- The final author version and the galley proof are versions of the publication after peer review.

- The final published version features the final layout of the paper including the volume, issue and page numbers.

Link to publication

\footnotetext{
General rights rights.

- You may freely distribute the URL identifying the publication in the public portal. please follow below link for the End User Agreement:

www.umlib.nl/taverne-license

Take down policy

If you believe that this document breaches copyright please contact us at:

repository@maastrichtuniversity.nl

providing details and we will investigate your claim.
}

Copyright and moral rights for the publications made accessible in the public portal are retained by the authors and/or other copyright owners and it is a condition of accessing publications that users recognise and abide by the legal requirements associated with these

- Users may download and print one copy of any publication from the public portal for the purpose of private study or research.

- You may not further distribute the material or use it for any profit-making activity or commercial gain

If the publication is distributed under the terms of Article $25 \mathrm{fa}$ of the Dutch Copyright Act, indicated by the "Taverne" license above, 


\title{
Role of Accessory Components in the Activation of Vitamin K-Dependent Coagulation Factors
}

\author{
J.L.M.L. van Rijn, R.F.A. Zwaal, H.C. Hemker, J. Rosing
}

Department of Biochemistry, Rijksuniversiteit Limburg, Maastricht, The Netherlands

Key Words. Prothrombin activation - Factor X activation · Phospholipids - Factor V . Factor VIII

Abstract. Kinetic studies of prothrombin activation and intrinsic factor X activation carried out in the absence and presence of phospholipids and the protein cofactors Va or VIIIa have provided insight in the mechanism by which the accessory components enhance coagulation factor activation. In intrinsic factor $\mathrm{X}$ and prothrombin activation, phospholipids cause a drastic drop of $\mathrm{K}_{\mathrm{m}}$ for the substrates factor $\mathrm{X}$ and prothrombin, whereas the protein cofactors factor $\mathrm{Va}$ and factor VIIIa increase $\mathrm{V}_{\max }$ of the prothrombin- and factor $\mathrm{X}$-activating reactions. The mode of action of factor $\mathrm{Va}$ in prothrombin activation is however somewhat more complex. Besides its stimulatory effect on the catalytic activity of factor $\mathrm{Xa}$, Factor $\mathrm{Va}$ also plays an important role in the assembly of the prothrombin-activating complex at phospholipid surfaces especially when the latter have a low affinity for vitamin-K-dependent coagulation factors. This effect is likely accomplished by promoting the binding of both prothrombin and factor $\mathrm{Xa}$ to the procoagulant surface.

\section{Introduction}

In the blood coagulation cascade, there are several reactions which require the presence of components, which by themselves have no enzymatic activity but which greatly stimulate coagulation factor activation [1]. These components, called nonenzymatic cofactors or accessory components, are divided in protein cofactors and negatively charged procoagulant surfaces. Enzyme, substrate and protein cofactors bind to the negatively charged surface and form an enzymatic complex that is optimally active in substrate activation. Thus, in the activation of the coagulation factors XII, XI and prekallikrein, enzyme-substrate interaction is promoted by their binding to negatively charged surfaces like kaolin, glass or sulfatides and by the protein cofactor high-molecular-weight kininogen. For the activation of the coagulation factors $\mathrm{X}$ and prothrombin the protein cofactors are: factor VIIIa for the intrinsic factor $\mathrm{X}$ activation, tissue factor protein for the extrinsic factor $\mathrm{X}$ 
activation and factor $\mathrm{Va}$ for prothrombin activation. The procoagulant surface, which promotes prothrombin and also extrinsic and intrinsic factor $\mathrm{X}$ activation, consists of phospholipid bilayers that contain negatively charged phospholipids. It is likely that under physiological conditions activated blood platelets provide the procoagulant surface that promotes the assembly of the prothrombin- and intrinsic factor-X-activating complexes since upon stimulation with thrombin plus collagen they expose negatively charged phosphatidylserine in the outer monolayer of their plasma membranes [2, 3].

The improvement of purification methods of the proteins involved in intrinsic factor $\mathrm{X}$ and prothrombin activation and the development of chromogenic substrates specific for thrombin and factor $\mathrm{Xa}$ made it possible to obtain via a kinetic approach insight in the role of the accessory components in these reactions. In this paper we will summarize kinetic studies carried out in our laboratory on prothrombin $[4,5]$ and intrinsic factor $\mathrm{X}$ activation [6]. The data obtained allow a precise quantitation of the stimulatory effects of the accessory components and also provide information about their mechanism of action in coagulation factor activation.

\section{Effect of the Nonenzymatic Cofactors on the Kinetic Parameters of Prothrombin and Factor $\mathbf{X}$ Activation}

Prothrombin and intrinsic factor $\mathrm{X}$ activation are the most intensively studied vitamin-K-dependent clotting factor activation reactions. They have many features in common. Both the enzymes (factor $\mathrm{Xa}$, factor IXa) and the substrates (prothrombin and factor $\mathrm{X}$ ) are vitamin $\mathrm{K}$-dependent proteins, which contain $\gamma$-carboxy glutamic acid residues that are important for the $\mathrm{Ca}^{2+}$-dependent binding of these proteins to negatively charged phospholipids. Both enzymes are serine proteases. Also the protein cofactors factor Va and factor VIIIa share several properties. They have no enzymatic activity of their own and both have to be activated by thrombin to express their function in the coagulation factor activation [7, 8]. Also factor $\mathrm{V}(\mathrm{Va})$ and factor VIII bind with a high affinity to phospholipid bilayers [9, 10], although they do not contain $\gamma$-carboxyglutamic acids.

The importance of the nonenzymatic cofactors is illustrated in table I. We have summarized the effects of the accessory components on the rates of prothrombin and factor $\mathrm{X}$ activation. It is clear that phospholipids and the protein cofactor stimulate coagulation factor activation in a multiplicative way. Maximal rates of prothrombin and factor $\mathrm{X}$ activation are obtained in the presence of both phospholipids and the protein cofactor (Va or VIIIa). In order to get more insight in the mode of action of phospholipids, factor $\mathrm{Va}$ and factor VIIIa in the prothrombin and factor $\mathrm{X}$ activation, we have determined their effects on the kinetic parameters of coagulation factor activation $[4,6]$. In the absence as well as in the presence of accessory components, Lineweaver-Burk plots for prothrombin and factor $\mathrm{X}$ activation were straight lines from which the kinetic parameters $\mathrm{K}_{\mathrm{m}}$ and $\mathrm{V}_{\max }$ could be determined. Table II summarizes the effects of the accessory components on the kinetic parameters for prothrombin and intrinsic factor $\mathrm{X}$ activation. These data indicate that the role of factor $\mathrm{Va}$ and factor VIIIa in prothrombin and factor $\mathrm{X}$ activation, respectively, is mainly restricted to an effect on $\mathrm{V}_{\max }$. Table II also 
Table I. Effect of nonenzymatic cofactors on relative rates of prothrombin and factor $\mathrm{X}$ activation

\begin{tabular}{llll}
\hline $\begin{array}{l}\text { Prothrombin } \\
\text { activator }\end{array}$ & $\begin{array}{l}\text { Relative rate } \\
\text { of prothrombin } \\
\text { activation }\end{array}$ & $\begin{array}{l}\text { Factor } \mathrm{X} \\
\text { activator }\end{array}$ & $\begin{array}{l}\text { Relative rate } \\
\text { of factor X } \\
\text { activation }\end{array}$ \\
\hline $\mathrm{Xa}$ & 1 & IXa & 1 \\
$\mathrm{Xa}, \mathrm{Ca}^{2+}$ & 2 & IXa, Ca & 8 \\
$\mathrm{Xa}, \mathrm{Ca}^{2+}, \mathrm{PL}$ & $5 \times 10^{2}$ & IXa, $\mathrm{Ca}^{2+}, \mathrm{PL}$ & $2.3 \times 10^{3}$ \\
$\mathrm{Xa}, \mathrm{Ca}^{2+}, \mathrm{Va}$ & $2.3 \times 10^{3}$ & IXa, Ca & - \\
$\mathrm{Xa}, \mathrm{Ca}^{2+}, \mathrm{PL}, \mathrm{Va}$ & $7.7 \times 10^{5}$ & IXa, $\mathrm{Ca}{ }^{2+}, \mathrm{PL}, \mathrm{VIIIa}$ & $5.3 \times 10^{6}$ \\
\hline
\end{tabular}

PL $=$ Phospholipid.

a $1 \mu M$ prothrombin, $5 \mathrm{mM} \mathrm{CaCl} 250 \mu$ phospholipid (phosphatidylserine $25 \%$, phosphatidylcholine $75 \%$, w/w) saturating factor Va.

b $1 \mu M$ factor $\mathrm{X}, 5 \mathrm{mM} \mathrm{CaCl}_{2}, 50 \mu M$ phospholipid (phosphatidylserine $25 \%$, phosphatidylcholine $75 \%$, w/w) saturating factor VIIIa.

reveals that the role of phospholipid in the factor-X- and prothrombin-activating complexes is restricted to an effect on $\mathrm{K}_{\mathrm{m}}$ for factor $\mathrm{X}$ and prothrombin. In the absence of phospholipid, the $\mathrm{K}_{\mathrm{m}}$ for prothrombin $(84 \mu M)$ and factor $\mathrm{X}(181 \mu M)$ are considerably higher than their plasma concentrations (prothrombin $1.5 \mu M$, factor $\mathrm{X} 0.2 \mu M$ ), whereas upon addition of phospholipid to both complexes, the $\mathrm{K}_{\mathrm{m}}$ drop to values well below the plasma concentrations. This allows both reactions to proceed at maximal velocity under physiological conditions, provided that a negatively charged phospholipid surface is present.

\section{Mode of Action of Phospholipids in Prothrombin and Factor $\mathbf{X}$ Activation}

Table III shows that the enzymatic complexes for factor $\mathrm{X}$ and prothrombin activation cannot be saturated by the addition of increasing amounts of phospholipid. $\mathrm{K}_{\mathrm{m}}$ is dependent on the phospholipid concentration such that $\mathrm{K}_{\mathrm{m}}$ for prothrombin and factor $\mathrm{X}$ increase with increasing phospholipid concentrations. Thus, $K_{m}$ measured in the presence of phospholipid must be regarded as an apparent $\mathrm{K}_{\mathrm{m}}\left(\mathrm{K}_{\mathrm{m}_{\mathrm{app}}}\right)$, which is a function of the phospholipid concentration in the reaction mixture.

In figure 1 , three models are presented which can explain the drop in $\mathrm{K}_{\mathrm{m}}$ after phospholipid addition as well as the apparent character of this kinetic parameter. The models are given for prothrombin activation in the absence of factor $\mathrm{Va}$ and are presumably also valid for intrinsic factor $\mathrm{X}$ activation in the absence of factor VIIIa. Model 1 illustrates the situation in which a phospholipidbound factor Xa molecule has a conformational state (asterisk) different from the factor $\mathrm{Xa}$ molecules in free solution. This conformational change of phospholipid-bound factor Xa causes an increase of the affinity of this molecule for prothrombin molecules which are present in free solution. This increased affinity between enzyme and sub- 
strate will result in a lowered $\mathrm{K}_{\mathrm{m}_{\mathrm{app}}}$ for prothrombin.

Also in model 2, prothrombin molecules originating from free solution interact directly with phospholipid-bound factor $\mathrm{Xa}$ molecules, but in this model the bound factor $\mathrm{Xa}$ molecules have not undergone a conformational change. Binding of prothrombin to phospholipid-bound factor $\mathrm{Xa}$ is promoted by the additional affinity of prothrombin to negatively charged phospholipid molecules in the direct environment of the factor $\mathrm{Xa}$ molecule (dashed circle). Both in model 1 and model 2, the saturation of factor $\mathrm{Xa}$ is directly dependent on the concentration of prothrombin free in solution. When the phospholipid concentration is increased, more prothrombin is bound to phospholipid leaving less prothrombin in solution available for interaction with phospholipid-bound factor Xa. To obtain half maximal saturation (i.e, $\mathrm{K}_{\mathrm{m}}$ conditions) of factor $\mathrm{Xa}$ with prothrombin, more prothrombin must be added at higher phospholipid concentrations. Since $\mathrm{K}_{\mathrm{m}}$ for prothrombin is expressed in terms of the concentration of total added prothrombin, $\mathrm{K}_{\mathrm{m}_{\text {app }}}$ will be higher at higher phospholipid concentrations (cf. table III).

In model 3, phospholipid-bound factor $\mathrm{Xa}$ activates phospholipid-bound prothrombin. In this model, half maximal saturation of bound factor $\mathrm{Xa}$ is determined by the local concentration of phospholipidbound prothrombin. The fact that the local prothrombin concentration at the phospholipid surface is higher than that in free solution explains the phospholipid-dependent decrease of $\mathrm{K}_{\mathrm{m}}$ for prothrombin. However, when the phospholipid concentration is again increased, the bound prothrombin molecules are diluted at the phospholipid surface and more prothrombin must be
Table II. Kinetic parameters of prothrombin and factor $\mathrm{X}$ activation

\begin{tabular}{|c|c|c|}
\hline $\begin{array}{l}\text { Prothrombin } \\
\text { activator }\end{array}$ & $\begin{array}{l}\mathrm{K}_{\mathrm{m}} \text { prothrom- } \\
\text { bin, } \mu M\end{array}$ & $\begin{array}{l}\mathrm{V}_{\max }, \mathrm{IIa} \cdot \\
\min ^{-1} \cdot \mathrm{Xa}^{-1}\end{array}$ \\
\hline $\mathrm{Xa}, \mathrm{Ca}^{2+}$ & 84 & 0.68 \\
\hline $\mathrm{Xa}, \mathrm{Ca}^{2+}, \mathrm{PL}$ & 0.11 & 2.56 \\
\hline $\mathrm{Xa}, \mathrm{Ca}^{2+}, \mathrm{PL}, \mathrm{Va}$ & 0.14 & 4,050 \\
\hline Factor $\mathrm{X}$ activator & $\begin{array}{l}\mathrm{K}_{\mathrm{m}} \text { factor } \mathrm{X} \\
\mu M\end{array}$ & $\begin{array}{l}\mathrm{V}_{\max }, \mathrm{Xa} \cdot \\
\min ^{-1} \cdot \mathrm{IXa}^{-1}\end{array}$ \\
\hline $\mathrm{IXa}, \mathrm{Ca}^{2+}$ & 181 & 0.01 \\
\hline $\mathrm{IXa}, \mathrm{Ca}^{2+}, \mathrm{PL}$ & 0.36 & 0.025 \\
\hline $\mathrm{IXa}, \mathrm{Ca}^{2+}, \mathrm{PL}, \mathrm{VIIIa}$ & 0.29 & 500 \\
\hline
\end{tabular}

The kinetic parameters were measured at $50 \mu M$ phospholipid vesicles containing $25 \mathrm{~mol} \%$ phosphatidylserine and $75 \mathrm{~mol} \%$ phosphatidylcholine.

$\mathrm{PL}=$ Phospholipid.

Table III. Effect of phospholipid on $\mathrm{K}_{\mathrm{m}}$ of prothrombin for prothrombin activation and $\mathrm{K}_{\mathrm{m}}$ of factor $\mathrm{X}$ for intrinsic factor $\mathrm{X}$ activation

\begin{tabular}{|c|c|c|c|}
\hline \multicolumn{2}{|c|}{ Prothrombin activation } & \multicolumn{2}{|c|}{$\begin{array}{l}\text { Intrinsic factor } \mathrm{X} \\
\text { activation }\end{array}$} \\
\hline $\begin{array}{l}\text { phospholipida } \\
\mu M\end{array}$ & $\begin{array}{l}\mathrm{K}_{\mathrm{m}} \\
\mu M\end{array}$ & $\begin{array}{l}\text { phospholipid } \\
\mu M\end{array}$ & $\begin{array}{l}\mathrm{K}_{\mathrm{m}_{\mathrm{app}}} \\
\mu M\end{array}$ \\
\hline 2.6 & 0.032 & 10 & 0.058 \\
\hline 10.5 & 0.068 & 20 & 0.139 \\
\hline 26.3 & 0.164 & 50 & 0.363 \\
\hline 52.6 & 0.25 & 75 & 0.409 \\
\hline 75 & 0.35 & 100 & 0.525 \\
\hline 105 & 0.48 & 150 & 0.822 \\
\hline \multirow[t]{2}{*}{240} & 1.08 & 200 & 1.83 \\
\hline & & 300 & 1.76 \\
\hline
\end{tabular}

In these experiments, neither factor Va nor VIIIa added.

a The phospholipid composition of the vesicles was $50 \mathrm{~mol} \%$ phosphatidylserine and $50 \mathrm{~mol} \%$ phosphatidylcholine.

b The phospholipid composition of the vesicles was $25 \mathrm{~mol} \%$ phosphatidylserine and $75 \mathrm{~mol} \%$ phosphatidylcholine. 


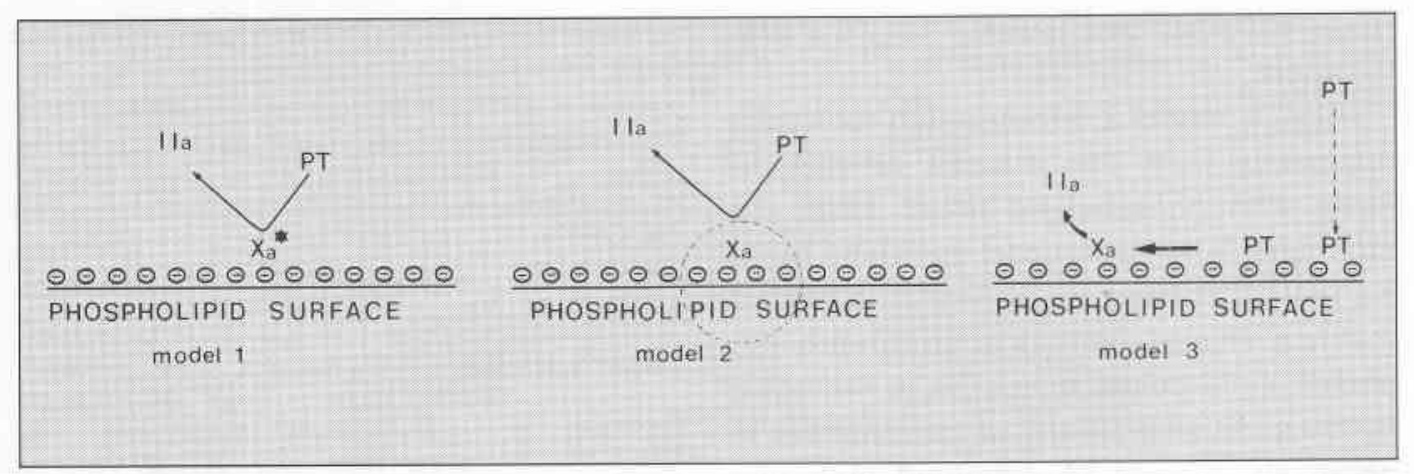

Fig. 1. Models for the mechanism of action of phospholipids in prothrombin (PT) activation in the absence of factor Va. In all three models, phospholipid causes a decrease of the $\mathrm{K}_{\mathrm{m}_{\mathrm{app}}}$ for prothrombin. For further explanations, see text.

added to restore the local concentration of phospholipid-bound prothrombin required for half saturation of phospholipid-bound factor Xa. Thus, when $\mathrm{K}_{\mathrm{m}}$ is expressed in terms of total prothrombin concentration, also in model $3 \mathrm{~K}_{\mathrm{m}_{\mathrm{app}}}$ will increase at increasing phospholipid concentrations. In this model, it is expected, that, although $\mathrm{K}_{\mathrm{m}_{\mathrm{app}}}$ increases with the phospholipid concentration, a $\mathrm{K}_{\mathrm{m}}$ expressed in terms of prothrombin surface density would be constant. Using binding parameters reported by Nelsestuen and Broderius [11] we calculated prothrombin and factor $\mathrm{X}$ surface densities at the $\mathrm{K}_{\mathrm{m}}$ presented in table III. Figure 2 compares the measured $\mathrm{K}_{\mathrm{m}_{\mathrm{app}}}$ for prothrombin or factor $\mathrm{X}$ with the surface density of bound prothrombin and factor $\mathrm{X}$, at the $\mathrm{K}_{\mathrm{m}}$ concentrations. It is obvious that $\mathrm{K}_{\mathrm{m}}$ expressed in terms of surface density is independent of the phospholipid concentration, as might be expected in model 3 .

In model 1 and model 2, the concentration of free substrate at $\mathrm{K}_{\mathrm{m}_{\mathrm{app}}}$ must be independent of the phospholipid concentration. Figure 2 shows that also the free prothrombin and factor $\mathrm{X}$ concentration at $\mathrm{K}_{\mathrm{m}}$ are inde- pendent of the phospholipid concentration. Thus, on the basis of these calculations, we cannot distinguish between the three proposed models, since both the free substrate concentration (requirement of model 1 and 2) and the surface density of substrate (requirement of model 3) are independent of and constant at different phospholipid concentrations.

Table IV shows the effect of variation of the molar fraction of phosphatidylserine in phospholipid vesicles on the kinetic parameters of prothrombin activation. In the absence of factor $\mathrm{Va}$, vesicles containing $40 \%$ phosphatidylserine exhibit a 40 -fold lower $\mathrm{K}_{\mathrm{m}_{\text {app }}}$ than vesicles containing $2.5 \%$ phosphatidylserine. Prothrombin affinity for phospholipid vesicles has been shown to increase at increasing content of phosphatidylserine in these vesicles [11]. Therefore, the difference in $\mathrm{K}_{\mathrm{m}_{\text {app }}}$ measured with phospholipid vesicles containing varying molar percentages phosphatidylserine is likely caused by differences of the affininty of prothrombin for these vesicles. In models 2 and 3 , a lower affinity of prothrombin for phospholipid results either in a lower affinity of the factor 


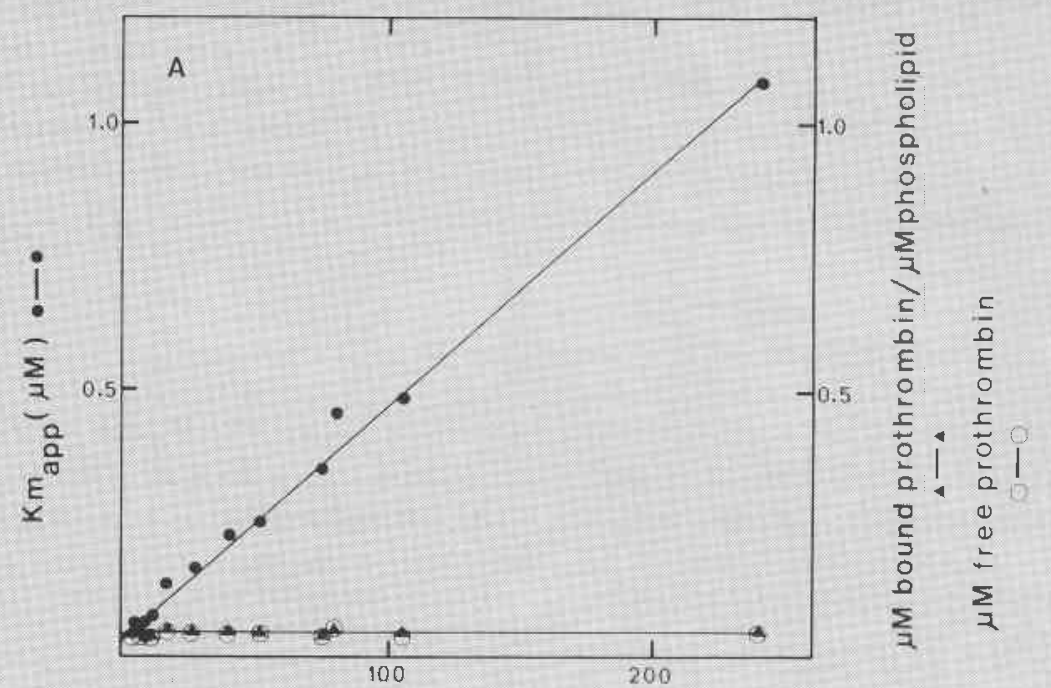

PHOSPHOLIPID $(\mu \mathrm{M})$

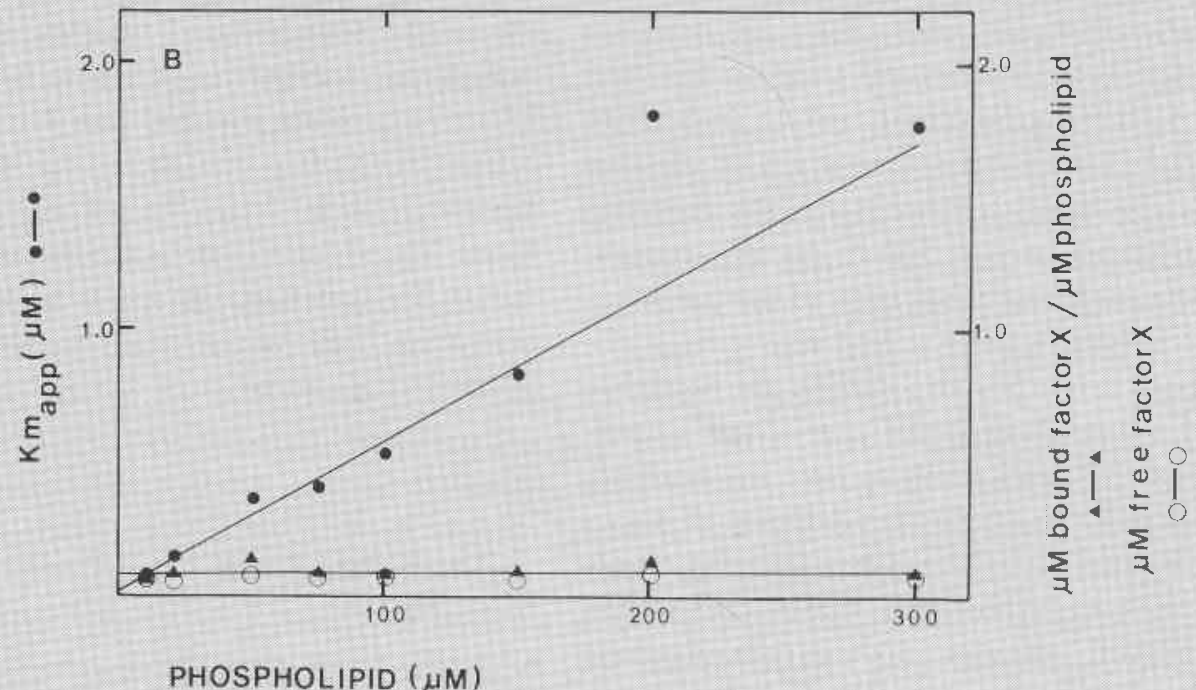

Fig. 2. Effect of increasing the phospholipid concentration on $\mathrm{K}_{\mathrm{m}_{\mathrm{app}}}(\bullet), \mathrm{Km}$ expressed in terms of substrate surface density $(\mathbf{\Delta})$ or $\mathrm{K}_{\mathrm{m}}$ expressed in terms of free substrate concentration (0). A Prothrombin activation. $\mathrm{B}$ Intrinsic factor $\mathrm{X}$ activation. 
Table IV. Effect of phospholipid vesicles with different phosphatidylserine content on the kinetic parameters of prothrombin activation in the absence of factor Va

\begin{tabular}{|c|c|c|c|}
\hline \multicolumn{2}{|c|}{ Vesicle composition } & \multirow{2}{*}{$\begin{array}{l}\mathrm{K}_{\mathrm{m}} \\
\mu M\end{array}$} & \multirow{2}{*}{$\begin{array}{l}\mathrm{V}_{\max } \\
\mathrm{IIa} \cdot \min ^{-1} \\
\mathrm{Xa}^{-1}\end{array}$} \\
\hline PS, $\%$ & $\mathrm{PC}, \%$ & & \\
\hline 40 & 60 & 0.17 & 3.33 \\
\hline 30 & 70 & 0.20 & 2.70 \\
\hline 20 & 80 & 0.19 & 2.00 \\
\hline 10 & 90 & 0.54 & 0.83 \\
\hline 5 & 95 & 1.66 & 0.33 \\
\hline 2.5 & 97.5 & 3.71 & 0.08 \\
\hline
\end{tabular}
line.

PS = Phosphatidylserine; $\mathrm{PC}=$ phosphatidylcho-

Kinetic parameters were determined at a phospholipid concentration of $50 \mu \mathrm{M}$.

Xa-phospholipid unit for prothrombin (model 2) or in a decreased prothrombin density at the phospholipid surface (model 3 ), which in both cases will result in an increase of $\mathrm{K}_{\mathrm{m}}$. In model 1, the charge of the phospholipid surface is expected to be unimportant for the conformational state of the phospholipid-bound factor $\mathrm{Xa}$, and moreover a decreased prothrombin binding to phospholipid will result in an increase of the concentration of prothrombin free in solution, which will cause a further decrease of $\mathrm{K}_{\mathrm{m}_{\mathrm{app}} \text {. }}$. We feel that on this basis and from the observation that acarboxyprothrombin, which has a reduced amount of $\gamma$-carboxyglutamic acids, gives in the presence of phospholipids much lower reaction rates than prothrombin [12], the conformational model (model 1) is less likely.

Also the $\mathrm{V}_{\max }$ of prothrombin activation depends on the amount of phosphatidylser-
Table V. Effect of phospholipid vesicles with different phosphatidylserine content on the kinetic parameters of prothrombin activation in the presence of factor $\mathrm{Va}$

\begin{tabular}{llll}
\hline \multicolumn{2}{l}{$\begin{array}{lll}\text { Vesicle composition } \\
\text { PS, \% }\end{array}$} & $\begin{array}{l}\mathrm{K}_{\mathrm{m}} \\
\mu M\end{array}$ & $\begin{array}{l}\mathrm{V}_{\max } \\
\mathrm{IIa} \cdot \mathrm{min}^{-1} \\
\mathrm{Xa}^{-1}\end{array}$ \\
\hline 40 & 60 & 0.33 & 3,750 \\
30 & 70 & 0.25 & 4,080 \\
20 & 80 & 0.11 & 4,170 \\
10 & 90 & 0.07 & 4,920 \\
5 & 95 & 0.07 & 4,420 \\
2.5 & 97.5 & 0.13 & 4,170 \\
\hline
\end{tabular}

PS = Phosphatidylserine; $\mathrm{PC}=$ phosphatidylcholine.

Kinetic parameters were determined at a phospholipid concentration of $50 \mu \mathrm{M}$.

ine in the phospholipid vesicles. At lower molar percentages of phosphatidylserine, lower $\mathrm{V}_{\max }$ values are observed. This is likely caused by the fact that these vesicles have a lower affinity for factor $\mathrm{Xa}$ and thus bind less factor $\mathrm{Xa}$, which will decrease the amount of factor $\mathrm{Xa}$ that participates in prothrombin activation. This will result in the observation of lower $\mathrm{V}_{\max }$ values.

\section{The Role of Factor Va in Prothrombin Activation}

As we have seen in table II, the stimulatory effect of factor $\mathrm{Va}$ on prothrombin activation in the presence of phospholipid vesicles with a high molar percentage of phosphatidylserine must be attributed to an increase of $\mathrm{V}_{\max }$ [cf. 4]. More recently it was observed 
Fig. 3. Prothrombin activation pathway. $\mathrm{PT}=$ Prothrombin; $\mathrm{E}=$ prothrombin-activating complex; $\mathrm{PT} 2=$ prothrombin $2 ; \mathrm{T}=$ thrombin; $\mathrm{F} 1.2$ = prothrombin fragment 1.2. Numbers $1-5$ designate the reaction steps explained in the text.

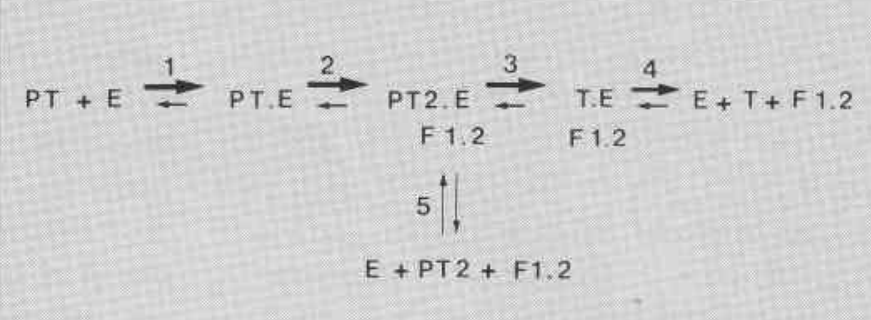

that factor $\mathrm{Va}$ also lowers $\mathrm{K}_{\mathrm{m}}$ for prothrombin for membranes with a low affinity for prothrombin [5, 13]. This effect of factor $\mathrm{Va}$ on $\mathrm{K}_{\mathrm{m}}$ for prothrombin will be discussed later.

The increase of the $V_{\max }$ by factor $\mathrm{Va}$ is the result of three additive effects: (1) a shift in the reaction pathway of factor-Xa-catalyzed prothrombin activation [4], (2) an increase of a forward rate constant in the prothrombin activation pathway [14] and (3) an increase of the amount of factor $\mathrm{Xa}$ that participates in prothrombin activation $[15,16]$.

Figure 3 gives the minimal reaction mechanism for prothrombin activation that will be helpful to explain the factor-Va-induced shift in the prothrombin activation pathway. Gelelectrophoretic analysis has shown that in the absence of factor $\mathrm{Va}$ prethrombin 2 is the main product of prothrombin activation [4]. This shows that the major reaction pathway occurring under these conditions is that represented by steps 1, 2 and 5, and it also indicates that prethrombin 2 easily dissociates from factor $\mathrm{Xa}$. In the presence of factor $\mathrm{Va}$ there is almost no prethrombin 2 formation, and thrombin is the major activation product. Thus, factor Va changes the pathway of prothrombin activation from one producing prethrombin 2 (steps $1,2,5$ ) into one giving rise to thrombin (steps 1-4). Apparently, the presence of factor Va prevents the dissociation of prethrombin 2 from the prothrombinase complex, thereby increasing the rate of thrombin formation.

Based on the estimation of the rate constants of prethrombin 2 formation (without factor $\mathrm{Va}$ ) and thrombin formation (with factor Va), Tans et al. [17] concluded that apart from the shift in the pathway factor Va must also increase at least one forward rate constant of the prothrombin activation pathway. This was indeed shown to be the case by Nesheim and Mann in 1983 [14]. From kinetic experiments with prothrombin and prothrombin activation intermediates they concluded that factor $\mathrm{Va}$ causes a 3,000-fold increase of the $\mathrm{k}_{\mathrm{cat}}$ of the factor-Xa-catalyzed cleavage of the $\mathrm{Arg}_{323}-\mathrm{Thr}_{324}$ bond in prothrombin (fig. 3 step 3 ).

The third effect of factor $\mathrm{Va}$ on $\mathrm{V}_{\max }$ of prothrombin activation concerns its ability to promote the binding of factor $\mathrm{Xa}$ to negatively charged phospholipid vesicles $[15,16]$. Especially for membranes with a low affinity for factor $\mathrm{Xa}$, this property of factor $\mathrm{Va}$ will contribute to the increase of the $V_{\max }$. This phenomenon becomes clear upon comparison of the effects of procoagulant surfaces with different phosphatidylserine content on $\mathrm{V}_{\max }$ measured in the absence (table IV) or presence of factor Va (table V). Without fac- 
tor $\mathrm{Va}$ there is a considerable decrease of $\mathrm{V}_{\text {max }}$ at low molar percentages of phosphatidylserine. This is likely caused by the fact that these membranes have a low affinity for factor Xa [11] hence less factor Xa will participate in prothrombin activation and lower $\mathrm{V}_{\max }$ values will be observed. However, in the presence of factor Va there is hardly any effect of variation of the molar percentage of phosphatidylserine on $\mathrm{V}_{\max }$ of prothrombin activation (table V). This indicates that under these conditions all added factor Xa participates in prothrombin activation irrespective of the affinity of the procoagulant membranes for factor Xa. This can be attributed to the fact that factor $\mathrm{Va}$ has the ability to promote the binding of factor $\mathrm{Xa}$ to the phospholipid vesicles.

Apart from the effects of factor $\mathrm{Va}$ on $V_{\max }$, table $\mathrm{V}$ also shows an effect of factor $\mathrm{Va}$ on $\mathrm{K}_{\mathrm{m}}$ for prothrombin when phospholipid vesicles with a low molar percentage phosphatidylserine are used as procoagulant surface. In the absence of factor Va, low molar percentages of phosphatidylserine gave high $\mathrm{K}_{\mathrm{m}}$ values. This could be easily explained in models 1 and 2 (fig. 2), in which the weak affinity of prothrombin for the phospholipid surface of vesicles containing low molar percentages of phosphatidylserine [11] results in a high $\mathrm{K}_{\mathrm{m}}$ for prothrombin. However, in the presence of factor Va the $\mathrm{K}_{\mathrm{m}}$ for prothrombin is low and independent of the molar percentage of phosphatidlyserine in the vesicles. So apparently, factor Va compensates for the loss of binding affinity of prothrombin for this kind of membrane surfaces. Several explanations are possible for the observation that factor Va lowers $\mathrm{K}_{\mathrm{m}}$ of prothrombin for procoagulant membranes with a low affinity for vitamin-K-dependent coagulation factors. This phenomenon can be accomplished by (1) a direct interaction of prothrombin with factor $\mathrm{Va},(2)$ a factor-Vainduced clustering of negatively charged phospholipid molecules around the enzymatic unit that creates a better surface for prothrombin binding or (3) a factor-Va-induced increase of a rate constant in the pathway of prothrombin activation that simultaneously increases the $\mathrm{k}_{\mathrm{cat}}$ and decreases the $\mathrm{K}_{\mathrm{m}}$. The third possibility can be explained with a simplified reaction scheme for serine proteases:

$$
\begin{aligned}
& \mathrm{E}+\mathrm{S} \stackrel{\mathrm{K}_{\mathrm{s}}}{\rightleftharpoons} \mathrm{ES} \underset{\mathrm{P}_{1}}{\stackrel{\mathrm{k}_{2}}{\longrightarrow}} \mathrm{EA} \stackrel{\mathrm{k}_{3}}{\longrightarrow} \mathrm{E}+\mathrm{A} \\
& \text { in which } \\
& \mathrm{k}_{\text {cal }}=\frac{\mathrm{k}_{2} \cdot \mathrm{k}_{3}}{\mathrm{k}_{2}+\mathrm{k}_{3}} \text { and } \mathrm{K}_{\mathrm{m}}=\mathrm{K}_{\mathrm{s}} \cdot \frac{\mathrm{k}_{3}}{\mathrm{k}_{2}+\mathrm{k}_{3}}
\end{aligned}
$$

In this mechanism it is possible that an increase of a single rate constant $\left(k_{2}\right)$ by factor $\mathrm{Va}$ can cause an increase of $\mathrm{k}_{\text {cat }}$ and $\mathrm{a}$ decrease of $K_{m}$. At present we cannot give preference to either of the three models since proper kinetic data that would allow discrimination are not yet available.

\section{Concluding Remarks}

The most important contribution of the phospholipid surface in the activation of vitamin-K-dependent coagulation factors is to promote the interactions between the proteins involved in these reactions. For this stimulatory effect, the proteins must have the ability to bind to the procoagulant surface. The stimulation by surface is caused by the fact that the proteins have an affinity for the phospholipid surface and for each other, a combination which ensures efficient proteinprotein interactions at the surface. Thus, 
phopholipids stimulate prothrombin and factor $\mathrm{X}$ activation by facilitating enzyme-substrate complex formation - a phenomenon which is reflected in a large drop of $\mathrm{K}_{\mathrm{m}}$ of their respective substrates.

The functions of the nonenzymatic protein cofactors, factors Va or VIIIa, are most easily explained on the basis of the effects of factor $\mathrm{Va}$ in prothrombin activation. It is shown that factor $\mathrm{Va}$ acts in prothrombin activation by enhancing the catalytic efficiency of factor $\mathrm{Xa}$, and by assembling factor $\mathrm{Xa}$ and prothrombin to an enzymatic complex at the phospholipid surface.

The marked effects of factor $\mathrm{Va}$ on the kinetic parameters of prothrombin activation, which are found in the presence of phospholipid vesicles with a weak affinity for factor Xa and prothrombin, are likely of physiological importance. It is generally accepted that in vivo stimulated blood platelets provide the procoagulant phospholipid surface that serves the activation of prothrombin and factor $\mathrm{X}$ since activated platelets expose phosphatidylserine in the outer monolayer of their plasma membrane. After activation with physiological platelet activators (collagen plus thrombin), the platelet outer monolayer contains, about $5 \mathrm{~mol} \%$ phosphatidylserine [1]. Such a membrane surface would show weak interactions with prothrombin and factor $\mathrm{Xa}$ in the absence of factor Va. Therefore, factor Va will also play an important role in the assembly of the prothrombinactivating complex at the surface of blood platelets. Since prothrombin and factor $\mathrm{X}$ activation have many common features, it is likely that phospholipids, factor VIIIa and activated blood platelets act in a similar way in intrinsic factor $\mathrm{X}$ activation as the corresponding cofactors in prothrombin activation.

\section{References}

1 Jackson, C.M.; Nemerson, Y.: Blood coagulation. A. Rev. Biochem. 49: 765-811 (1980).

2 Bevers, E.M.; Comfurius, P.; van Rijn, J.L.M.L.; Hemker, H.C.; Zwaal, R.F.A.: Generation of prothrombin-converting activity and the exposure of phosphatidylserine at the outer surface of platelets. Eur. J. Biochem. 122: 429-436 (1982).

3 Rosing, J.; van Rijn, J.L.M.L.; Bevers, E.M.; Van Dieijen, G.; Comfurius, P.; Zwaal, R.F.A.: The role of activated platelets in prothrombin and factor $\mathrm{X}$ activation. Blood 65: 319-332 (1985).

4 Rosing, J.; Tans, G.; Govers-Riemslag, J.W.P.; Zwaal, R.F.A.; Hemker, H.C.: The role of phospholipids and factor $\mathrm{Va}$ in the prothrombinase complex. J. biol. Chem. 255: 274-283 (1980).

5 Van Rijn, J.L.M.L.; Govers-Riemslag, J.W.P.; Zwaal, R.F.A.; Rosing, J.: Kinetic studies of prothrombin activation: effect of factor $\mathrm{Va}$ and phospholipids on the formation of the enzyme-substrate complex. Biochemistry 23: 4557-4564 (1984).

6 Van Dieijen, G.; Tans, G.; Rosing, J.; Hemker, H.C.: The role of phospholipid and factor VIIIa in the activation of bovine factor X. J. biol. Chem. 256: 3433-3442 (1981).

7 Nesheim, M.E.; Myrmel, K.H.; Hibbard, L.; Mann, K.G.: Isolation and characterization of single chain bovine factor V. J. biol. Chem. 254: 1326-1334 (1979).

8 Vehar, G.A.; Davie, E.W.: Preparation and properties of bovine factor VIII (antihemophilic factor). Biochemistry 19: 401-410 (1980).

9 Bloom, J.W.: Nesheim, M.E.; Mann, K.G.: Phospholipid-binding properties of bovine factor $\mathrm{V}$ and factor Va. Biochemistry 18: 4419-4425 (1979).

10 Lajmanovich, A.; Hudry-Clergeon, G.; Freyssinet, J.M.; Marguerie, G.: Human factor VIII procoagulant activity and phospholipid interaction. Biochim. biophys. Acta 678: 132-136 (1981).

11 Nelsestuen, G.L; Broderius, M.: Interaction of prothrombin and blood-clotting factor $\mathrm{X}$ with membranes of varying composition. Biochemistry 16: 4172-4177 (1977).

12 Dahlbäck, B.; Stenflo, J.: Inhibitory effect of activated protein $C$ on the activation of prothrombin by platelet-bound factor Xa. Eur. J. Biochem. 107: $331-335$ (1980).

13 Pusey, M.L.; Nelsestuen, G.L.: The physical signif- 
icance of $\mathrm{K}_{\mathrm{m}}$ in the prothrombinase reaction. Biochem. Biophys. Res. Commun. 114: 526-532 (1983).

14 Nesheim, M.E.; Mann, K.G.: The kinetics and cofactor dependence of the two cleavages involved in prothrombin activation. J. biol. Chem 258: 5386-5391 (1983).

15 Nesheim, M.E.; Taswell, J.B.; Mann, K.G.: The contribution of bovine factor $\mathrm{V}$ and factor $\mathrm{Va}$ to the activity of prothrombinase. J. biol. Chem. 254: 10952-10962 (1979).

16 Lindhout, T.; Govers-Riemslag, J.W.P.; Van de Waart, P.; Hemker, H.C.; Rosing, J.: Factor Vafactor Xa interaction. Effects of phospholipid vesicles of varying composition. Biochemistry 21 : 5494-5502 (1982).
17 Tans, G.; Rosing, J.; van Dieijen, G.; Hemker, H.C.: Conjectures on the mode of action of factors $\mathrm{V}$ and VIII; in Mann, Taylor, The regulation of coagulation, pp. 173-185 (Elsevier/North Holland, Amsterdam 1980)

\section{J. Rosing,}

Department of Biochemistry,

Rijksuniversiteit Limburg,

Beeldsnijdersdreef 101,

NL-6216 EA Maastricht (The Netherlands) 